\title{
Tragedia y filosofía: Eurípides y los antecedentes de la dialéctica socrático-platónica
}

\section{María Teresa Padilla Longoria}

\begin{abstract}
Muerto el arte de la conversación no sirve ya más que para evocar las cosas que solíamos hablar en otros tiempos y apenas uno que otro libro consigue concretar el tono de lo que ha sido pensado en el curso de una conversación ... o de una vida.
\end{abstract}

Salvador Elizondo

\section{I}

\section{ntroducción}

Los seres humanos somos ontológica y constitutivamente incompletos, insuficientes, relativos. Debido a esta insuficiencia esencial, los hombres tratamos de buscar diferentes medios de compleción, de relación, de intercambio. Uno de los medios ideales para tratar de compensar esta insuficiencia es la conversación, el diálogo. El llegar a ser conscientes de esta incompleción tomó tiempo, e igualmente, el captarlo en forma escrita. La primera forma escrita de autoconciencia fue poética. La poesía griega fue uno de los más eminentes ejemplos de esta conciencia poética. La conciencia poética homérica, hesiódica y lírica es una conciencia heroica y trágica: el hombre es un ser sufriente y mortal, un ser limitado, pero tiene una gama de posibilidades vitales abiertas para llegar a ser mejor o para alcanzar automejoramiento. Esta conciencia trágica aparece en la tragedia como una conciencia de la condición humana apresada en el diálogo hablado/escrito la cual es una conciencia literaria y dialéctica: nosotros somos seres inquisitivos y responsables. La conciencia poética griega es una conciencia humanística que alcanza su punto más elevado en la cristalización de una conciencia ética con Sócrates y Platón. ${ }^{1}$

La razón por la cual hemos ido tan atrás para tratar de trazar los antecedentes de la dialéctica, es porque el diálogo platónico representa no solamente lo

${ }^{1}$ Está generalmente aceptado que la tradición homérica fue, originalmente, oral. El punto es que, en un momento dado, ésta devino una tradición escrita y nosotros la tomaremos como tal. 
que la filosofía es, sino también lo que la humanidad debe ser. La idea socrático-platónica de la filosofía como diálogo es un proyecto humanístico: la filosofía es un método de vida para aprender cómo llegar a ser un mejor ser humano.

A nuestro juicio, podemos encontrar dos clases de diálogos en la literatura griega: metafórico y real. Ambas clases de diálogo nos muestran un género de búsqueda humana por compleción a través de la conversación. El sentido metafórico del diálogo está presente en la épica y la lírica griegas y responde a una profunda necesidad de comunicación, de compartir e interiorizar valores. Esto es, la necesidad de diálogo tiene sus raíces en la naturaleza humana. El diálogo real está presente en la tragedia y, particularmente, en los debates en la tragedia que se asemejan a aquellos en un tribunal de justicia. El diálogo platónico tiene sus raíces en este diálogo real, pero puesto que Platón tiene preocupaciones humanísticas, los sentidos metafóricos del diálogo representan un antecedente importante de su idea de la filosofía.

\section{Tragedia}

Nuestro siguiente e inevitable paso es clarificar la relación entre diálogo y

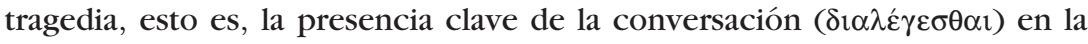
estructura de la tragedia. Es verdad que en Homero nosotros podemos apreciar la presencia de personajes bien desarrollados. En Hesíodo podemos distinguir un patrón similar con sus personajes reflexivos. El punto es que las obras de Homero y Hesíodo son todavía poemas narrativos y el narrador tiene que presentar a cualquier personaje o suceso del relato a los lectores. En la lírica nosotros podemos apreciar conversaciones metafóricas, pero no diálogos directos entre personajes independientes. Lo que es definitivo es que el diálogo o la forma o estructura dialógica es, por otra parte, esencial a la tragedia. Este diálogo abierto y la confrontación entre personajes independientes nos podría permitir hablar acerca de una dialéctica de la tragedia. Es en la tragedia en donde nosotros encontramos por primera vez una extensa representación de la actividad dialógica humana. Esto es, podemos apreciar diferentes géneros de discursos humanos -incluyendo los soliloquios y los

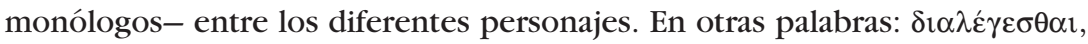
como conversación humana es obvia en la tragedia. ${ }^{2}$ En este sentido, la tragedia es un antecedente literario directo del estilo platónico formal dialógico de escribir.

${ }^{2}$ Un buen ejemplo de esta forma dialógica intensa e intrínseca a la tragedia podría ser encontrado en Esquilo, Los siete contra Tebas, particularmente en 375-652. 
En este artículo propondremos que: I. El contenido dialógico de la tragedia incluye una reflexión poética sobre la condición humana trágica. Debido a nuestra insuficiencia humana necesitamos comunicación y compleción. El drama representa una manera de compleción en sus personajes heroicos. El dramaturgo los retrata de tal manera que nosotros podemos apreciar el proceso en el cual ellos adquieren esta autoconciencia trágica a través de conversaciones bien definidas. El mensaje moral de esta conversación trágica es central en la medida en que contiene dos puntos principales: 1. Una propuesta de un modelo de hombre y 2 . Un modelo comunitario de humanidad. II. Mostraremos que, en el caso particular de Eurípides, la forma dialógica es central porque él ilustra con sus tragedias el modo específico de intercambios verbales que tiene muchas similitudes formales con la idea socráticoplatónica de la dialéctica como un método filosófico de conversación a través de preguntas y respuestas.

\section{Contenido dialógico de la tragedia}

La tragedia es central para nuestros propósitos. En la tragedia, la conciencia poética adquiere una forma definitiva a través del diálogo. Lo que la tragedia añade en relación con la épica y la lírica es que los personajes están hablando directamente uno con el otro. Además, los personajes están conversando abiertamente acerca de la condición humana y ellos están conscientes de que, esta condición, oscila entre la necesidad - lo que está determinado- y la libertad -lo que es posible cambiar. En la tragedia es perceptible que los personajes están conversando acerca de los valores -y el reto personal que éstos implican para su consecución- como una forma preeminente para completar la naturaleza humana.

La tragedia es fundamental en el proceso de aparición de la autoconciencia humana.

Socialmente hablando, la tragedia fue una actividad que estuvo presente en la comunidad a través de la institución de certámenes trágicos. Estéticamente hablando, la tragedia es una creación nueva como género literario. Psicológicamente hablando, la tragedia implica un cambio humano profundo en la medida en que el hombre y la conciencia trágica adquieren su forma definitiva a través de la representación formal de diálogos reales. ${ }^{3}$

La invención de la tragedia entraña algo nuevo en la experiencia humana: la idea de que los seres humanos somos inquisitivos, receptivos y responsa-

3 Véase Jean-Pierre Vernant y Pierre Vidal-Naquet, Mythe et tragédie en Grèce ancienne. París, Maspero, 1981, vol. 1, p. 27. 
bles. Expliquémonos. El sentido trágico de la responsabilidad implica la representación de personajes independientes quienes están hablando abierta y directamente acerca de sí mismos y de su actividad. En la tragedia los seres humanos son una pregunta para sí mismos. La acción humana deviene problemática y es un objeto de "reflexión poética". Entender el mensaje de los poetas trágicos implica comprender lo que la conciencia trágica entraña, esto es, que todo lo que está relacionado con los seres humanos es una pregunta abierta. ${ }^{4}$ La escenificación trágica deviene central porque ella representa una amplia gama de las experiencias humanas como un objeto de entendimiento dialógico. La experiencia trágica contiene un profundo significado humano, produce una reflexión en el auditorio y, valiéndose del diálogo, nos muestra muchas y diferentes maneras humanas de actuar.

Los tres poetas trágicos -Esquilo, Sófocles y Eurípides- presentan diferentes rasgos en sus caracterizaciones de la conciencia humana trágica a través de conversaciones. Nosotros nos centraremos en el caso de Eurípides.

\section{Eurípides}

Los personajes de Eurípides son presentados muchas veces en debates internos o legales. Esto será central para captar los orígenes de la retórica y la dialéctica. ${ }^{5}$

El pathos euripídeo pone en tensión dos fuerzas humanas: lo racional y lo irracional -este último está, en ocasiones, adyacente al horror.

Las tragedias de Eurípides ponen en tela de juicio muchos de los valores que se pensaban inmutables: lo que prevalece son la decisiones engañosas entre los hombres, la condición de la mujer será transformada hasta que ellas obtengan buena fama y prestigio. ${ }^{6}$

Eurípides es un explorador inquisitivo del alma humana en sus sentimientos y pasiones más contradictorias. Él combina estas preocupaciones con las influencias que recibe de la filosofía como conocimiento racional de la realidad y el estudio del ser humano como materia o tema.

Eurípides gusta poner en contraste y hacer énfasis -como la mayoría de los poetas épicos, líricos y trágicos- en las dichas y desgracias humanas. Él tiene la peculiaridad de representar personajes diestros en la crítica, quienes manifiestan la intrínseca y problemática naturaleza de los seres humanos y el cuestionamiento de todo lo que fue aceptado convencionalmente.

\footnotetext{
${ }^{4}$ Véase $i$ bid, p. 9.

${ }^{5}$ Este punto lo desarrollaremos más adelante.

${ }^{6}$ Véase Eurípides, Medea, 410-420.
} 
La comprensión de la conciencia trágica nos revelará una simple verdad: somos seres limitados. Nosotros adquirimos autoconocimiento a través de la experiencia y, preeminentemente, a través de las relaciones dialógicas en vivo. El heroísmo y la autoconciencia están unidos como una aventura humana permanente de redescubrimiento de lo que los seres humanos somos y de qué posibilidades humanas tenemos.

Ejemplificaremos con algunos de los dramas de Eurípides. Empecemos con Medea. El personaje de Medea es presentado como el de una mujer que lleva en su seno una serie de desgracias. Su personaje combina también una naturaleza arrogante e impulsiva. Eurípides contrasta el personaje de Medea con el de la Nodriza. Este último trata de aconsejar a Medea sobre la gran importancia acerca de la diferencia entre moderación y exceso:

NODRIZA. - Puesto que una moderada fortuna tiene un nombre que es el más justo de pronunciar sobre la lengua y, en la práctica es, por mucho, la cosa más beneficiosa para los mortales. Pero las riquezas excesivas no procuran ningún provecho para los mortales, y cuando la divinidad está cargada de ira contra una casa, aquéllas hacen la ruina más grande. ${ }^{7}$

Medea profiere una pregunta moral capital: ¿por qué Zeus no dio a los mortales los medios claros para distinguir -como una clase de huella digital-al hombre bueno del malo? Pero la Nodriza y Medea hacen hincapié en el punto de que la clave para una vida buena y moderada reside en la coherencia entre tus pensamientos, tus palabras y tus actos. El peso de cada palabra es central y ésa es la razón por la cual Eurípides nos hace notar que la lengua moderada revela la condición personal interna de uno mismo como armoniosa. ${ }^{8}$

En el último soliloquio 9 Medea está consciente de que su desgracia procede de su propio orgullo; ella sabe la clase de crímenes que cometerá, pero su ira es más poderosa y seductora, ya que ésta sobrepasa sus cálculos. Eurípides nos muestra, de acuerdo con la tradición, que cualquier género de pasión cegadora es la causa principal de males para los mortales. Nuevamente el motivo final de su crimen es un asunto de honor público: ella no puede aceptar haber sido ridiculizada por sus enemigos.

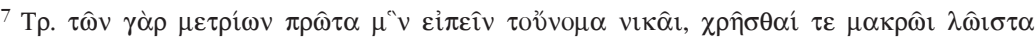

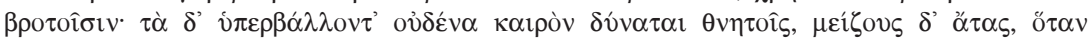

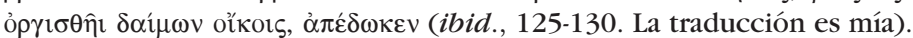

${ }^{8}$ Véase ibid., 465-519.

${ }_{9}$ Véase ibid., 1019-1080. 
Después de que Medea ejecuta sus crímenes, ella misma concluye con una sentencia final relacionada con la condición humana trágica: nuestra naturaleza mortal y nuestra vida es, a veces, afortunada, pero nunca feliz. De este modo, para Medea, los dioses siempre conducen a los seres humanos por caminos inexplicables.

Hécuba contiene el dilema de una mujer que, por un lado, ve perdida su condición, su pasado y sus tiempos felices y, por otro, su doloroso presente. Su dilema moral está puesto en términos de su propia condición o situación especial: ¿cómo puede ella continuar manteniendo el honor a pesar del hecho de que está envuelta en la desgracia? En diferentes discursos el personaje de Hécuba, en conversaciones intensas con otros caracteres presenta la inestabilidad de la fortuna humana, la condición humana trágica y las diferentes maneras en las que los seres humanos somos dependientes de muchas cosas que están más allá de nuestro control y límites:

HÉCUBA. - ¡Oh dolor! ¡Parece que hay una gran lucha en puerta, una lucha repleta de gemidos y no carente de lágrimas! ¡Y ahora, como se ve, no he muerto, cuando yo debía morir y Zeus no me mató, sino que me mantuvo viva, para que vea, solamente, pobre infeliz, nuevas desgracias todavía mayores que las anteriores! ${ }^{10}$

En esta tragedia la naturaleza humana se opone a la educación. Uno nace bueno o malo y es imposible cambiar este hecho. No obstante, el llegar a ser bien y correctamente educado implica un aprendizaje de lo que es bueno. Esta lección nos permite distinguir lo que es deshonroso de lo que no lo es. ${ }^{11}$

Eurípides hace énfasis en Hécuba respecto a que el hombre precavido debe buscar siempre la armonía entre sus palabras y sus actos. El mensaje final de la Hécuba de Eurípides está relacionado con el hombre prudente. Éste es aquel que no mezcla lo justo con lo injusto y quien es enseñado por el tiempo que la reflexión es superior al apresuramiento. De tal modo que, el hombre sabio y valiente, es aquel que es precavido y quien mantiene la calma en el momento oportuno:

HécuBA.- Agamenón, las lenguas de los hombres nunca deben tener más fuerza que sus actos: si un hombre ha hecho buenas acciones, su

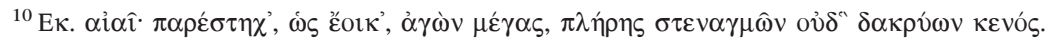

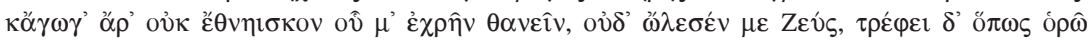

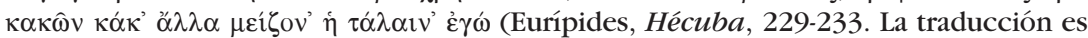
mía). Véase también, 282-285; 583-584; 721-722; 956-960.

${ }^{11}$ Véase Eurípides, Не́cuba, 592-600.
} 
discurso debe ser bueno, si malas, entonces sus palabras deberían sonar falsas, y él nunca debería ser capaz de causar injusticia a uno que tiene reputación de justo. Inteligentes son los hombres que han adquirido maestría en este arte, pero su inteligencia no perdura hasta el final. Ellos perecen de una muerte terrible: ninguno, hasta ahora, se ha escapado. $^{12}$

La conciencia trágica es en Hécuba un asunto de equilibrio personal en nuestras relaciones. A pesar del hecho de que la vida humana está sujeta a muchos factores externos que la constriñen, es posible, para los seres humanos, mantener armonía en nuestro modo de actuar. La clave se encuentra en la deliberación y reflexión antes de hablar y actuar.

No obstante, el hecho de que Eurípides introduce muchos elementos nuevos en sus tragedias, mantiene la visión de la tradición épica y lírica en relación con los seres humanos: somos seres contingentes y dependientes; la mejor manera para mantener una vida digna reside en el reconocimiento de nuestras limitaciones y en la decisión libre de hacer un esfuerzo para mantener una conducta moderada.

Hécuba es una tragedia que nos muestra esto, ya que concentra esta idea que es común en la épica y la lírica: Eurípides nos manifiesta, a través de sus personajes reflexivos en diálogos que, a pesar del hecho de que estamos constreñidos de muchas maneras, somos capaces de mantener una vida virtuosa que se centra en la moderación. La moderación y la armonía son un resultado del pensamiento y la conversación profundos.

En las Suplicantes, Teseo presenta ante Adrasto que el argumento de que la vida humana contiene más cosas negativas que positivas es falso. Teseo piensa que, si eso fuera cierto, la vida humana en la tierra sería imposible. Agradece a Prometeo por habernos provisto con entendimiento y con medios para vivir. Piensa que los problemas humanos empiezan porque los seres humanos como tales rompemos el equilibrio con una actitud arrogante: desafiamos a los inmortales porque pensamos que nosotros somos más sabios que ellos. Asimismo, Teseo critica fuertemente la inconciencia, porque considera que si los seres humanos conociéramos nuestras miserias, al mismo tiempo deberíamos conocer que nuestra vida es lucha. Los dioses juegan de una manera veleidosa con los mortales: a veces, nos dan éxito; a veces, infortunios.

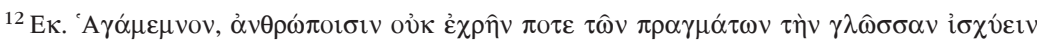

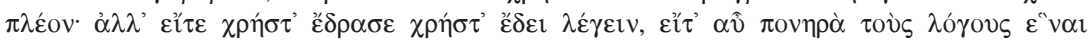

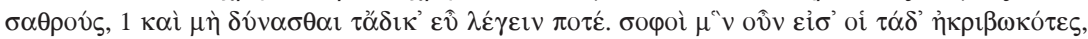

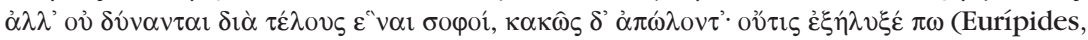
Hécuba, 1187-1194. La traducción es mía). 
No obstante, el hombre afortunado da honores a los inmortales con el propósito de mantener su suerte; el desafortunado con el fin de obtenerla. En la medida en que nosotros llegamos a ser conscientes de estas fluctuaciones podemos dirigir nuestras vidas de una manera temperada. ${ }^{13}$ Con lo que respecta al punto del papel central de las palabras en la vida humana, Adrasto dice:

ADRASTO.- ¿Oh Zeus, por qué los hombres dicen que los desventurados mortales tienen alguna sabiduría? Nosotros dependemos de ti y hacemos lo que tú deseas. [...] iOh mortales insensatos, quienes disparan más allá del blanco y con razón sufren gran calamidad, tú no aprendes de tus amigos, sino únicamente de los acontecimientos! Ciudades, ustedes podrían ponerle fin a sus infortunios por la palabra, pero dirimen sus asuntos con la sangre! ${ }^{14}$

Podemos apreciar que Eurípides otorga un peso importante al papel de las palabras y del lenguaje en la resolución de problemas humanos. Eurípides devela la naturaleza humana como conflictiva y violenta, pero al mismo tiempo, como capaz de recobrar la paz y el equilibrio. Si las conversaciones humanas son finalmente importantes, lo son porque ellas nos proveen de algo positivo: automejoramiento y compleción individual y comunitaria. El diálogo es un camino para la autocomprensión y para el entendimiento mutuo.

En Las troyanas Eurípides presenta una gran variedad de diálogos y debates que nos muestran las diferentes características de la naturaleza humana. Esto es central, ya que es una manera en la cual Eurípides apresa lo que la conciencia trágica es: un proceso dialógico permanente de autoconocimiento y descubrimiento de nuestras limitaciones y posibilidades para llegar a ser mejores o peores. Él insiste, repetidamente, que nadie puede oponerse al destino. ${ }^{15}$

En un largo debate -entre Hécuba y Helena y ante Menelao cuando Helena está debatiendo por su vida- Hécuba trata de mostrar a Helena que no todo en la vida es un resultado del azar. Hécuba declara que no es lo mismo seguir los pasos de la fortuna, simplemente como ellos son, que seguir los pasos de

${ }^{13}$ Véase Eurípides, Suplicantes, 195-249; 419-510.

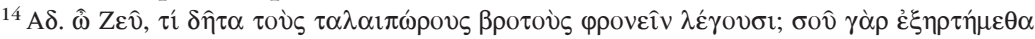

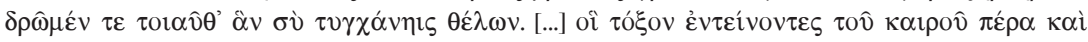

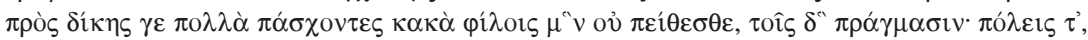
"̌́ 736, 745-749. La traducción es mía).

${ }^{15}$ Véase Eurípides, Las troyanas, 636-683. 
la virtud reflexiva y decisiva ante la fortuna cambiante. ${ }^{16} \mathrm{~A}$ pesar de los reveses de la fortuna, nosotros deberíamos mantener a la inteligencia y a la mesura como las maestras más honestas. De este modo nosotros actuamos de acuerdo con Zeus, porque él conduce los asuntos humanos de una manera justa.

La conclusión de esta tragedia - una conclusión que es similar a las visiones generales de Esquilo y de Sófocles- es que el hombre honesto es aquel que asume su condición trágica, esto es, su naturaleza mortal y contingente con las posibilidades y limitaciones que ésta entraña. El hombre honesto ama la moderación que implica discreción, mesura y justicia; de la misma manera él reconoce el poder de los dioses y la necesidad humana de sometimiento al rigor absoluto del destino.

\section{La forma dialógica en Eurípides}

El drama retrata de una manera artística los dilemas humanos reales derivados de la tragedia de la insuficiencia humana y la permanente búsqueda por compleción. El drama representa -entre otra clase de conversaciones- intercambios agonísticos que retratan diferentes géneros de diálogos. Algunas veces las conversaciones se dan entre personajes opuestos en conflicto -como cuando Eurípides imita los argumentos legales en sus tragedias. Esto es, el principal propósito de cualquier debate es ganar. El interlocutor que muestra más habilidad y persuasión para convencer a su auditorio acerca de cualquier caso en particular gana, sin tener en cuenta su verdad o falsedad.

El debatir entraña medios y fines polémicos; a veces justificados, a veces no. El debatir puede involucrar motivaciones personales o meramente subjetivas o intereses que serán defendidos a toda costa.

La tragedia jugará un papel clave en la explicación de los antecedentes de la filosofía y de la retórica y también en su nacimiento. La tragedia trata de representar los diferentes géneros de conversaciones que los seres humanos tenemos por el mero hecho de serlo y de anhelar autocompleción. Los diferentes géneros de conversaciones se desarrollan en el contexto de diferentes actividades humanas. Las conversaciones ordinarias pueden ser acerca de cosas triviales y sólo acerca de ellas y no tener mayores repercusiones. Pero hay un género de conciencia filosófica común que todos los seres humanos tenemos, en el sentido de que el hombre ordinario se hace preguntas fundamentales acerca de él mismo y del mundo. El punto es que la filosofía toma estas preguntas y trata de darles respuestas metódicas y racionales. La filosofía empieza

16 Véase ibid., 860-1059. 
como una actividad autoconsciente. Ella recibe y asume, racionalmente, el legado ordinario, poético (épico, lírico y trágico), religioso y político de la conciencia humana forjada por largo tiempo y le da una dirección sistemática que primero cristaliza en la filosofía como tal y, después, en una ética particularmente constituida como una conciencia moral en la figura de Sócrates. ${ }^{17}$ Éste asume como fundamento de su reflexión ética los dos preceptos délficos: "conócete a ti mismo" y "nada en demasía". El propósito de la filosofía -y de cualquier búsqueda filosófica- es el tener una mirada más cuidadosa hacia las cosas ordinarias y el tratar de dar una explicación racional de éstas.

La tragedia retrata otra clase de conversaciones. La gente ordinaria tiende también a debatir. En estas conversaciones los interlocutores muy probablemente estarán convencidos de que sus motivos son buenos. El propósito de esto debates es simplemente ganarlos. Sófocles y Eurípides ilustran debates cuasi legales. De nuevo, el propósito de esta clase de debate es agonístico: el interlocutor que muestra más persuasión, astucia y habilidad para convencer a su auditorio ganará el debate o el caso en disputa. ${ }^{18}$ Éste es el origen de la retórica. La presentación de los debates en Sófocles es natural y de acuerdo con el desarrollo normal de la tragedia. Pero es importante notar que las tragedias de Eurípides contienen, en esta representación de los debates legales, una estructura dialógica formal: sus personajes tratan de explicar, a través de un proceso de pregunta y respuesta, los motivos de sus acciones, la consideración de los pros y los contras. Los personajes de Eurípides tienden a exponer sus casos mediante un proceso de racionalización y de consideración deliberada de sus acciones. Todo este proceso de dar una explicación entraña un paralelismo entre los personajes de Eurípides y la dialéctica socráticoplatónica. No es una mera coincidencia el que los personajes de Eurípides frecuentemente usen expresiones que parecen representar mucho más un argu-

${ }^{17}$ La religión nos da otra perspectiva sobre la conciencia humana. Ella nos proporciona una clara distinción y contraste entre un sujeto humano independiente y diferenciado quien establece un vínculo y una relación con una deidad. El contraste entre la majestuosidad divina y la pequeñez humana es otra fuente de conciencia humana. Esta conciencia religiosa es, nuevamente, un reconocimiento de insuficiencia. La política contribuye también en este proceso de constitución de la conciencia racional. Los seres humanos empiezan a vivir como individuos en una comunidad organizada con leyes y, en consecuencia, con responsabilidades y fines personales y sociales. Este contraste e interacción individuo-sociedad es otra fuente de entendimiento del hombre mismo como entidad relativa, esto es, como un individuo en y con relaciones y responsabilidades.

${ }^{18}$ En relación con este tema vale la pena consultar C. Collard, "Formal Debates in Euripides' Drama”, en Ian McAuslan y Peter Walcot, eds., Greek Tragedy. Oxford, Universidad de Oxford, 1993, pp. 153-166. 
mento racional que un simple drama. Un buen ejemplo de esto es mostrado en Las troyanas en la conversación entre Hécuba, Menelao y Helena en la exposición del caso de Helena del cual cito una parte:

MENELAO.- ¿Qué es esto? ¡Tú tienes una nueva forma de rezarles a los dioses!

HÉCuBA.- Apruebo, Menelao, tu decisión de matar a tu esposa. Pero no la mires, o ella te llenará de vehemente deseo y te hará su prisionero. Ella atrapa la mirada de los hombres, toma ciudades, lanza fuego en las casas; ella tiene tal poder encantador. Yo la conozco como tú y todas sus víctimas.

HelENA.- Menelao, tus acciones asestan la más alarmante nota para mí, pues teniendo a tus sirvientes, éstos hacen uso de la fuerza para sacarme de aquí delante de estas tiendas. Sospecho que me odias, pero, aun así, quiero hacerte una pregunta: ¿qué han decidido tú y los griegos, he de vivir o no?

MENELAO.- No hay necesidad de hacer un recuento de los votos; todo el ejército te entregó a mí para que te matara, puesto que fui víctima de tus crímenes.

HELENA.- ¿Puedo, entonces, responder a esto y razonar que, si muero, mi muerte será injusta?

MENELAO.- No he venido aquí con la intención de debatir, sino de matarte.

HécuBA.- Déjala hablar, así, ella podrá morir habiendo tenido ese derecho y concédeme la tarea de poner el caso en su contra. Tú no sabes nada acerca del sufrimiento que ella causó en Troya. Todos los cargos en su contra sucintamente expuestos serán ejecutorios y la dejarán sin escapatoria alguna.

MenElaO.- Esta concesión que tú pides va a consumir tiempo. Pero si ella desea hablar, puede hacerlo. Ten por seguro, no obstante, que yo le permitiré hacer esto por deferencia a lo que tú has dicho, no por ninguna consideración para con ella.

HELENA.- Tal vez te rehusarás a hacerles frente a mis consideraciones, ya sea que pienses que ellas sean correctas o no, puesto que tú me juzgas como a una enemiga. Yo responderé a los cargos que, supongo, pondrás en mi contra y presentaré, ante ti, contraargumentos. ${ }^{19}$

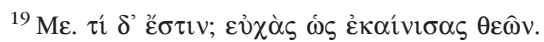

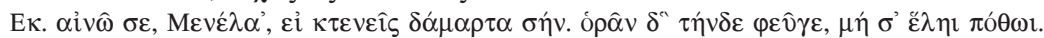

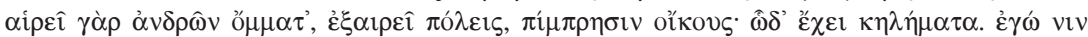

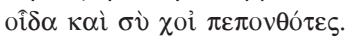


De hecho, Eurípides ha sido sumamente criticado por esta práctica, ya que sus críticos piensan que él rompe con el desarrollo natural de la tragedia y que sólo quiere hacer uso de esas digresiones como una clase de demostración retórica en detrimento de la esencia o del encanto real del drama. ${ }^{20} \mathrm{El}$ rasgo más característico de los debates formales de Eurípides es que ellos son emocionales en sus motivos, combativos en las premisas y uno de sus personajes, a veces, propone un reto abierto para discutir. ${ }^{21}$ A pesar de este propósito agonístico, la mayoría de las tragedias de Eurípides terminan en acuerdo, pero hay siempre un ganador del debate. Esto es crucial, porque el objetivo de Eurípides es que su audiencia pudiera llegar a simpatizar con el ganador, puesto que, normalmente, la victoria entraña un asunto, ya sea político, de honor moral o de reputación.

Además, los debates legales ${ }^{22}$ representan la clave para conectar la tragedia como antecedente formal de la dialéctica en el sentido de un método dialógico que implica la argumentación de un punto -esto es, un caso- a través de preguntas y respuestas entre, al menos, dos interlocutores. Como Collard escribe:

En los debates legales los discursos están plagados, exactamente como estaban en las cortes legales de la Atenas contemporánea, con todo tipo de color y de narrativa emocional, o con alegatos especiales; y están cuidadosamente organizados con virajes calculados del ataque a la defensa, con anticipaciones del argumento del oponente, con llama-

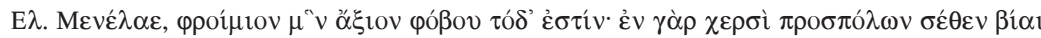

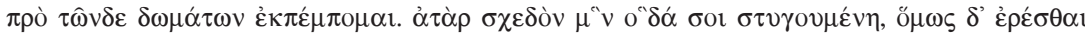

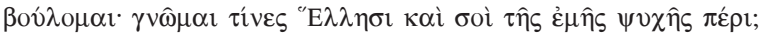

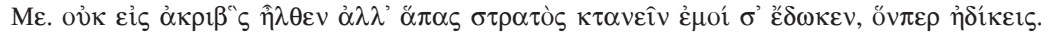

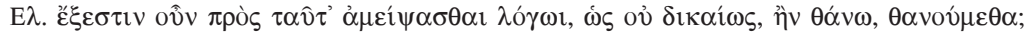

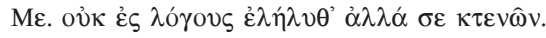

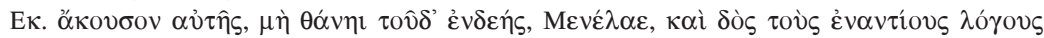

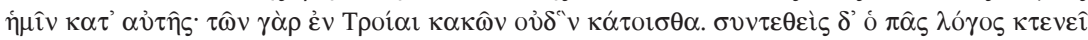

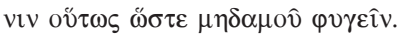

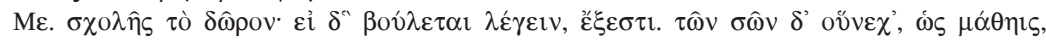

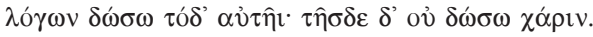

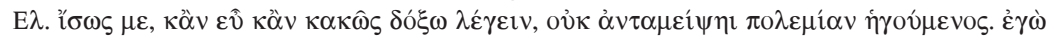

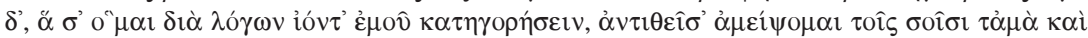
$\tau \grave{\alpha} \sigma^{\prime} \alpha i \tau \iota_{\alpha} \mu \alpha \tau \alpha$ (Eurípides, Las troyanas, 889-918. La traducción es mía).

${ }^{20}$ En relación con esta crítica dirigida a Eurípides véase J.-P. Vernant y P. VidalNaquet, op. cit., vol. I, p. 74.

${ }^{21}$ Véase C. Collard, "Formal debates in Euripides' drama", en op. cit., p. 155.

${ }^{22}$ Algunos ejemplos de debates legales en las tragedias de Eurípides pueden ser encontrados en Hipólito, 902-1089; Heracles, 111-287; Fenicias, 453-637; Andrómaca, $547-765$. 
dos a la probabilidad y al recurso sentencioso superior a las verdades morales. Se completa la transferencia de la imaginación desde el $\delta \imath \kappa \alpha \sigma$ -

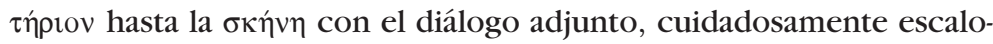
nado en donde precede a los discursos largos, en su variedad desde la pregunta y la contestación metódica hasta las aceleraciones del ritmo repentinas en cuanto se abre una grieta en la defensa, o, después de los discursos principales de los cargos y la refutación vehemente, de la recriminación, de la hostilidad y el desafío, que son las materias normales para terminar los debates formales, ganando, así, teatralmente del ambiente forense. ${ }^{23}$

\section{Tragedia y filosofía}

Permítaseme aclarar algunos puntos. Las raíces directas y el comienzo de la filosofía como dialéctica en el sentido platónico del término están: 1. En el nacimiento de la filosofía como tal con Tales de Mileto y los demás presocráticos, quienes fueron los primeros filósofos en la medida en que ellos hicieron preguntas y contestaron algunas de ellas rigurosa y metódicamente, esto es, independientemente de motivaciones pragmáticas y, 2. En las conversaciones de Sócrates, particularmente, en aquellas que nos muestran el modo en que las conversaciones filosóficas tienen que ser desarrolladas.

Los antecedentes literarios directos de la filosofía como dialéctica están en la poesía griega, esto es, en la poesía épica, la lírica y la tragedia -y particularmente en la forma de los debates legales reales y en la representación de éstos. La filosofía empieza como una actividad autoconsciente; ella asume y desarrolla racionalmente la "conciencia poética" de sus antecedentes literarios. Las conversaciones filosóficas son metódicas y tienen el propósito de buscar la verdad.

Los debates retóricos son una respuesta para las necesidades humanas pragmáticas: ganar una conversación ordinaria, una discusión formal, o un caso. Las conversaciones socráticas, y la permanente inquisición que ellas contienen, no tiene constricciones en lo absoluto. Es una búsqueda libre y dialógica de la verdad.

En otras palabras, las tragedias de Eurípides dramatizan debates con recursos, motivaciones y propósitos literarios. ${ }^{24}$ Platón escribe diálogos filosóficos

23 C. Collard, "Formal debates in Euripides' drama", en op. cit., pp. 157-158 (la

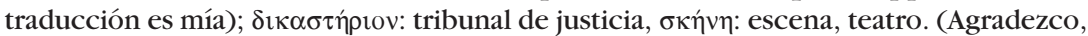
de veras, a Arlene Hall el haber revisado la traducción de esta cita).

${ }^{24}$ Hay diferentes opioniones en relación con los orígenes reales y los propósitos literarios de los debates formales de Eurípides. Collard comparte la visión de Duchemin: 
con maestría literaria, pero sus motivaciones y propósitos son estrictamente filosóficos. Esto es, la forma y contenido de sus escritos son un todo dialéctico inseparable. Esto no significa que la forma en la cual Eurípides presenta sus dramas -y particularmente sus debates legales- no muestre similitudes claras y pudiera representar un modelo formal y un antecedente literario del estilo platónico de escritura.

Muchas cosas han sido dichas en relación con la cuestión de por qué Platón escribió en una forma dialógica. Para clarificar esta pregunta, que conduce a la original en nuestro argumento general -esto es, la pregunta acerca de los orígenes de la dialéctica- es necesario plantear otra pregunta que la complementa y clarifica: ¿por qué Sócrates no escribió nada? La primera respuesta podría ser, porque Sócrates personifica al filósofo ideal y a la manera ideal de hacer filosofía, esto es, la conversación metódica, en vivo que pone todo a prueba. La vida y la obra de Sócrates son un todo indiscernible. Lo que carac-

"Jacqueline Duchemin has claimed that tragedy's agonistic character and particularly its formal debates -are in part its natural inheritance from a long popular or pastoral tradition of dramatic poetry- a primitive mimetic poetry, she means, of alternating or amoibaic form, which represents two contrasted characters or interests. She notes that debates as an established dramatic form, the agon of tragedy, appear first in Sophocles and Euripides (that is, in the surviving plays, the earliest of which, the Ajax, is generally put at $c .450$ B.C.); but they are absent from Aeschylus. Earlier, she had drawn attention to two other literary forms strongly reliant on the formal opposition of characters or forces. One of these, comedy, developed its idiosyncratic agon well before the formal debate became established in tragedy; Duchemin's other analogy, the historians' use of contrast as mode in dramatic narrative or reported argument, is less cogent from the point of synchronism but indicative in a general way of her truth. The spoken word, and especially the reported argument, is as natural to Greek historiography as it is to Greek poetry, let alone poetic drama, when we consider the chief place of oral epic in time and influence in the Greek literary tradition. Duchemin therefore sees Aeschylus' use of alternating and pointed dialogue, especially stichomythia, as the linear ancestor of the more stylized exchanges in Sophocles and Euripides; she suggests that, while the sudden appearance of formal debates in Sophocles an Euripides around 450 is chiefly through the influence of contemporary developments in sophistic argument and rhetorical technique, it is certainly not due entirely to the sophists or rhetors. Rather, tragedy owes much to the sophists, but may itself have influenced them, from the time of its own sudden growth in Aeschylus' lifetime; it may actually have provided some kind of model for their agonistic discourses

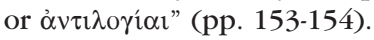

Desmond Conacher en su Euripides and the Sophists (Duckworth, Londres, 1998), expresa lo siguiente: “...The influence of Sophistic rhetoric on Euripides is almost a cliché of literary studies of his plays. This influence is clearly discernible in the structure and the rhetorical devices of the speeches (rhêseis), but it is particularly true of the markedly 'agonistic' ones, i.e., those in which leading characters indulge in the set speeches of formal debate, involving, for example, political ideologies (as at 
terizó la actitud de Sócrates fue su diálogo directo y su aproximación dubitativa y racional hacia las cosas.

La personalidad y el estilo de vida de Sócrates debieron haber sido extremadamente atractivos para muchos de sus contemporáneos -como lo son para muchos estudiosos hoy en día. La prueba de ello es que tuvo muchos seguidores, imitadores y parodiadores a lo largo de la historia. ${ }^{25}$ Muchos autores antiguos han representado las conversaciones socráticas por escrito. Está claro que Platón no fue la primera persona que escribió e imitó las conversaciones socráticas. Pero, como Diógenes Laercio escribe:

Ellos [la gente] dicen que Zenón de Elea fue el primero en escribir diálogos. Pero, de acuerdo con Favorino en sus Memorabilia, Aristóteles en el primer libro de su diálogo Sobre los poetas afirma que fue Alexámeno Estireo o Teyo. Pero en mi opinión, fue Platón, quien llevó esta forma de escribir a la perfección, y debe ser declarado con justicia el ganador del premio por su invención así como por su embellecimiento. ${ }^{26}$

Está claro también que Platón no fue el creador de la filosofía, ${ }^{27}$ pero el fundamento de lo que la filosofía debe ser se cristaliza y se consolida en su

Supplices 409-62), dynastic rivalry (as at Heraclidae $134 \mathrm{ff}$.) or personal animosity (as at Medea $446 \mathrm{ff}$.).

[...] we need to remember that the influence of Sophistic ideas on Euripides' dramaturgy was part of a larger whole, involving style, language and rhetorical technique. Moreover, since rhetoric formed so large part of the Sophist's training for 'the good life' (itself associated with political succes), it would be surprising if there were not some overlap between their views on rhetoric and their views on 'values' (political and ethical)" (p. 50). Nosotros estamos de acuerdo con C. Collard, ya que encontramos que su explicación es más plausible y porque pensamos que, aunque es innegable que hay una influencia de la sofística sobre Eurípides, es menos fuerte de lo que normamente se piensa. A mi juicio, los motivos de Eurípides son todavía y principalmente, literarios, esto es, él es un dramaturgo que tiene el propósito de crear y desarrollar una tragedia con todos los recursos artísticos e influencias que pudiera considerar apropiados presentar para alcanzar sus propósitos literarios.

${ }^{25}$ En relación con el tema de la figura de Sócrates véase, D. Clay, "The Origins of the Socratic Dialogue", en Paul A. Vander Waerdt, ed., The Socratic Movement. Ithaca, Universidad de Cornell, 1994, pp. 23-47.

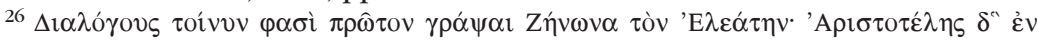

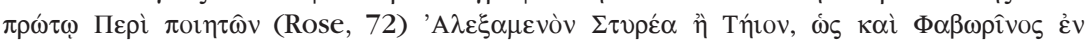
'А

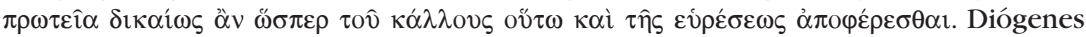
Laercio, Vidas de los filósofos eminentes, III, 48, 1-6 (la traducción es mía).

${ }^{27} \mathrm{Cf}$. Andrea Wilson Nightingale, Genres in Dialogue. Plato and the Construct of Philosophy. Cambridge, Universidad de Cambridge, 1997, pp. 1-12. 
proyecto de filosofía como dialéctica. En esta idea platónica de la filosofía como dialéctica la figura de Sócrates es central. Mejor dicho: el proyecto platónico de filosofía es incomprensible sin la presencia de Sócrates. Sócrates estuvo consciente de la filosofía presocrática y de la aparición de esta actividad nueva y diferenciada que estaba centrada en una aproximación racional, desinteresada hacia las cosas. Él desarrolla y concreta esta nueva actividad como una forma de vida metódica. Platón, por su parte, fue testigo de los orígenes y desarrollo de la filosofía y del proyecto filosófico socrático. La grandeza filosófica de Platón consiste en verter en forma y contenido la esencia del acto filosófico. Ésta es la razón por la cual Platón define su proyecto como dialéctica (diálogo filosófico): porque él entiende la esencia de la filosofía como un acto inevitablemente dialéctico, como aquel en el cual vivir es pensar por nosotros mismos o preferentemente, en diálogo con otros, del pasado y del presente, y examinarlo todo.

A propósito de esto dice Platón en el Gorgias:

SóCRATES.- Escucha, pues, Gorgias. Deberías saber que yo estoy convencido de ser una de esas personas que en una conversación con alguien más, realmente quieren tener un conocimiento del objeto acerca del cual se habla. Y también te considero a ti una de ellas.

GORGIAS. - ¿Por qué lo dices?

Sócrates.- Déjame decírtelo ahora. Tú puedes saber con certeza que yo no sé cuál es la persuasión derivada de la oratoria acerca de la cual tú has estado hablando ahora, o acerca de qué materias persuade. Aunque tengo mis sospechas acerca de qué persuasión te refieres y acerca de qué persuade, todavía te voy a preguntar tan sólo acerca de lo mismo que dices, de la persuasión que es producida por esta oratoria y acerca de qué. ¿Y por qué, cuando yo tengo mis sospechas, te pregunto y me abstengo de expresarlas yo mismo? No es tras de ti de quien estoy, sino de nuestra conversación, la cual debe proceder de tal manera que hagamos que las cosas acerca de las cuales estamos hablando, sean más claras para nosotros. Examina, pues, si te parece justa mi manera de interrogar $[\ldots]^{28}$

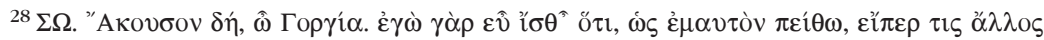

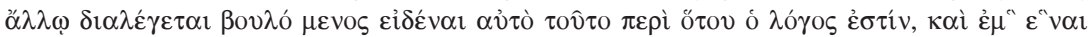

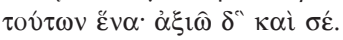

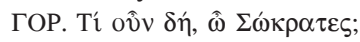

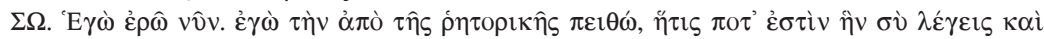

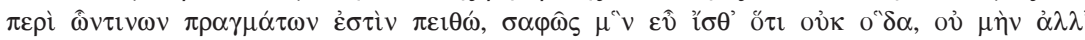

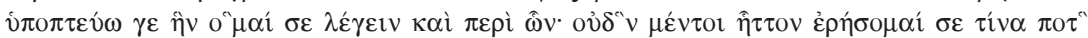


No es de extrañarse que las preguntas de Sócrates y su estilo de vida fueran tan irritantes. La filosofía empieza como una actividad preeminente de indagación, de investigación que pone todo en duda. Sócrates fue sumamente irritante con sus preguntas porque, a pesar de que todos hacemos esas preguntas fundamentales por el hecho de ser hombres, la mayoría de las personas comunes y corrientes tienden a evadirlas, ya que hay muchos problemas pragmáticos, urgentes, y prioridades por resolver. Algunas de estas personas dan respuestas "interesadas" a estas preguntas fundamentales de acuerdo con sus motivaciones particulares sin tener en cuenta la verdad. La gente resiste, pero Sócrates persiste. Sócrates y Platón consolidan a la filosofía como una indagación metódica, como una actividad que pone en duda todo aquello que se daba por descontado o era considerado seguro. La filosofía empieza, así, como una actividad perturbadora.

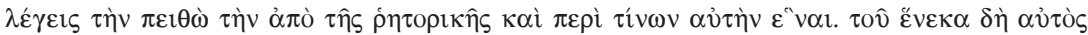

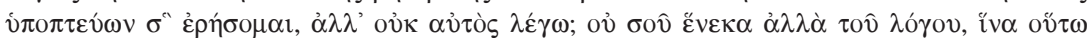

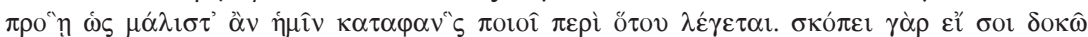

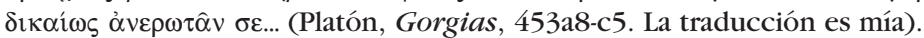

